\title{
Strengthening of Nurul Ilmi Mosque with Concrete Jacketing
}

\author{
Fauzan Febrin Anas Ismail ${ }^{1}$, Siska Apriwelni ${ }^{2}$, Imelia Faradiza ${ }^{2}$, Zev Al Jauhari ${ }^{2}$
}

\begin{abstract}
Nurul Ilmi moesque is one of building for worship located in University of Andalas. In 2008 the new building of mosques was designed using previous indonesian seismic code, SNI 1726: 2002. The right side of the new mosque was constructied in 2009. Due to the limitation of the budget, the construction of the left side of the mosque was continued on 2014. However, a new indonesian seismic code SNI 03-1726-2012 was established and the designed mosque should be revised based on the new indonesian seismic code. Since the right side of the mosque was designed by using the old seismic code (SNI 1726: 2002), so it is necessary to evaluate the strength of the structure by using the seismic code (SNI 03-1726-2012). Based on the analysis results, it was found that the right side of the building structure is not strong enough to resist the combination loads acting on the structure, especially the earthquake load. Therefore, it is necessary to strengthening (retrofitting) the right side of the building structure before connecting with the left side of the building. In this study, the concrete jacketing method was used to the retrofit the column structure. The results show that the jacketing method is effective to increase the capacity of the column and reduce internal forces and displacements that occur in the structure of the mosque, so the structure can resist the working loads
\end{abstract}

Keywords-column, concrete jacketing, earthquake, displacement, strengthening.

\section{INTRODUCTION}

$\mathbf{N}$ urul Ilmi mosque is a building for worship used by students, lecturers, and employees who were in the neighborhood Andalas University campus. As the number of students at the University of Andalas increase every year, the mosque should be expanded which can accommodate more pilgrims. In 2008, the new mosque was designed using old seismic code, SNI 03-1726-2002 [1]. The right side of the mosque was built in 2009 refer to the design. In 2014, the left side of mosque has been planned to be constructed. However, the design of mosque should be revised base on the new seismic code SNI 03-1726-2012. The left side of the mosque was constructed based on the revised design in 2014.

Since the right side of the mosque was designed using old seismic code (SNI 1726: 2002), so it is necessary to evaluate the strength of the existing structure using the new seismic code SNI 03-1726-2012 before connecting with the right side of the mosque (Figure 1)

\footnotetext{
${ }^{1}$ Department of Civil Engineering, Andalas University, Limau Manis Campus, Padang, Indonesia (corresponding author to provide phone: +62 751-72497; fax: +62-751-71301; e-mail: fauzan@ft.unand.ac.id)

${ }^{2}$ Disaster Study Center of Andalas University, (e-mail: zevaljauhari@gmail.com siskaapriwelni@gmail.com).
}

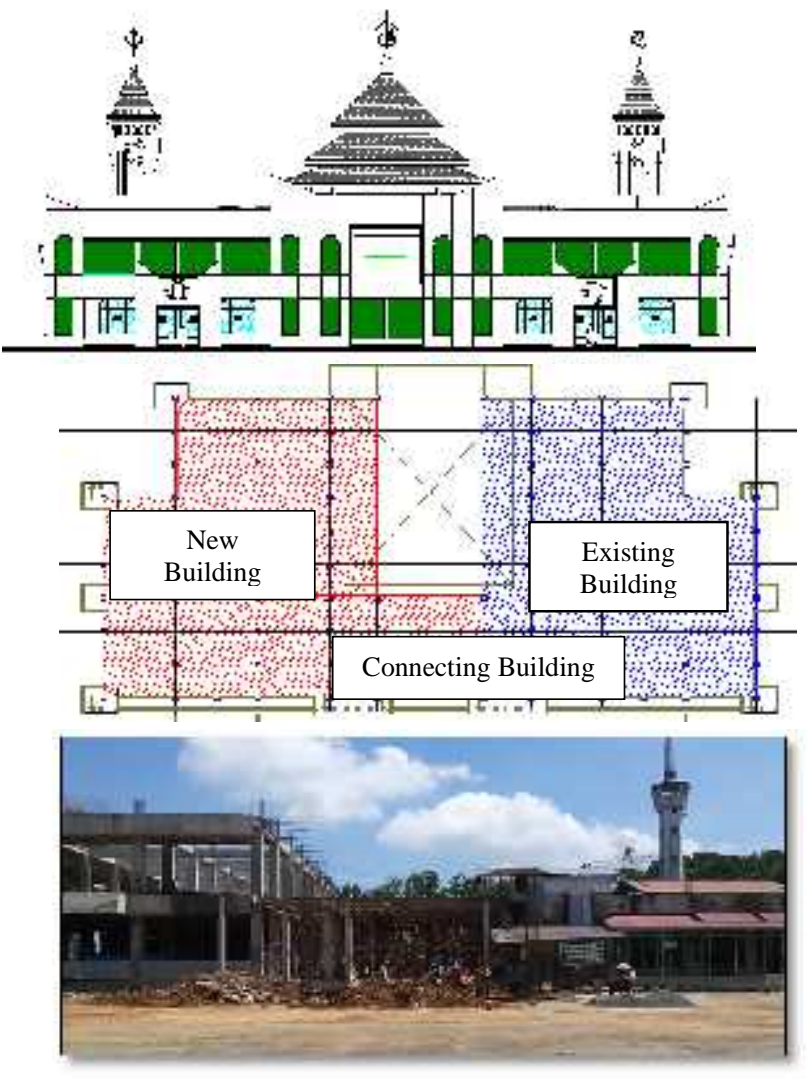

Fig 1. The Plan and View of Nurul Ilmi Mosque Building

\section{MOSQUE BUILDING STRUCTURE ANALYSIS}

Before analyzing the right side of the mosque building, it is necessary to collect data and information of the building.

\subsection{Properties of Material}

To get the right quality of concrete building mosques, testing was done by hammer test. Hammer test results showed that compressive strength of the concrete for columns is $\mathrm{K}$ 250 (fc'=22,5 Mpa). Meanwhile, the number of reinforcement obtained by testing with ferroscan tool. Yield stress of steel reinforcement bar, fy $=350 \mathrm{MPa}$.

\subsection{Structure Analysis}

Based on the data that has been described previously as well as by function and location of the building, the structure of the mosque building subsequently modeled and analyzed using commercial structural analysis software ETABS 9.7.4 [3]. The seismic load based on SNI 1726:2012 was used in this study. According to the soil test result, the soil on the building was classified as soft soil. The respon spectra of 
mosque location (Padang city) with soft soil category was obtained from the website http://puskim.pu.go.id/ Aplikasi/desain_spektra_indonesia_2011. After performing the structural analysis, further analysis of the capacity of cross-section beams and columns was carried.

\subsection{Load-Carrying Capacity of Beams and Columns}

Table 2.1 shows the flexure capacity of beam. From the table, it can be seen the flexure capacity of beam is stronght enough, the Nominal Moment of the beam (Mn) is higher than the Moment ultimate $(\mathrm{Mu})$. Meanwhile, the capacity of column is not sufficient. Based on the analysis capacity of the column cross-section through the P-M interaction diagram (Fig. 2), most axial forces and bending moments exceed the interaction diagram. This means that the structural columns of the mosque is not enough axial and flexural capacity to resist the working loads.

Table 2.2 shows the shear capacity of the column. As seen in the Table, the shear capacity of the column is sufficient, nominal shear is higher than the ultimate shear $(\mathrm{Vu})$.

Table 2.1 The Capacity of Bending Momen in The Beam

\begin{tabular}{|c|c|c|c|c|c|c|c|}
\hline \multirow[t]{2}{*}{$\begin{array}{l}\text { Beam } \\
\text { Code }\end{array}$} & \multicolumn{2}{|c|}{ Dimension } & \multicolumn{2}{|c|}{ Reinforcement } & \multicolumn{2}{|c|}{ Momen } & \multirow[t]{2}{*}{$\begin{array}{c}\mathrm{Mu} \\
<\mathrm{Mn}\end{array}$} \\
\hline & Width & Height & Bottom & Top & Nom & Ult & \\
\hline $\begin{array}{c}\text { B1 } \\
30 \times 60\end{array}$ & 300 & 600 & 5 D 19 & $3 \mathrm{D} 19$ & 20,319 & 15,24 & OK \\
\hline
\end{tabular}

Table 2.2. The Capacity of Shear Force in The Column

\begin{tabular}{|c|c|c|c|c|c|c|}
\hline \multirow[t]{2}{*}{ Code } & \multirow{2}{*}{$\begin{array}{l}\text { Flexure } \\
\text { Reinfor } \\
\text { cement }\end{array}$} & \multicolumn{2}{|c|}{$\begin{array}{c}\text { Shear } \\
\text { Reinforcement }\end{array}$} & \multicolumn{2}{|c|}{$\begin{array}{c}\text { Shear Reinforcement } \\
\text { Installed }\end{array}$} & \multirow[t]{2}{*}{$\mathrm{Vu}<\mathrm{Vn}$} \\
\hline & & $\underset{(\mathrm{mm})}{\mathrm{d}}$ & $\begin{array}{c}\mathrm{s} \\
(\mathrm{mm})\end{array}$ & $\underset{(\mathrm{mm})}{\mathrm{d}}$ & $\begin{array}{c}\mathrm{s} \\
(\mathrm{mm})\end{array}$ & \\
\hline \multicolumn{7}{|l|}{ 1st Floor } \\
\hline $\mathrm{K} 140 \mathrm{X} 40$ & $8 \mathrm{D} 19$ & 10 & 17,5 & 10 & 10 & $\mathrm{OK}$ \\
\hline K1 D45 & $8 \mathrm{D} 19$ & 10 & 20 & 10 & 10 & OK \\
\hline K2 D60 & $16 \mathrm{D} 19$ & 10 & 27,5 & 10 & 10 & $\mathrm{OK}$ \\
\hline K2 55X55 & $16 \mathrm{D} 19$ & 10 & 25 & 10 & 10 & $\mathrm{OK}$ \\
\hline \multicolumn{7}{|l|}{ 2nd Floor } \\
\hline K2 D60 & 16 D 19 & 10 & 27,5 & 10 & 10 & OK \\
\hline K2 55X55 & $16 \mathrm{D} 19$ & 10 & 25 & 10 & 10 & OK \\
\hline
\end{tabular}

Table 2.3 Inter Story Drift of Existing Building

\begin{tabular}{|c|c|c|c|c|c|c|c|}
\hline Code & $\begin{array}{l}\text { St } \\
\text { or } \\
y\end{array}$ & UX & $\begin{array}{l}\text { High } \\
\text { Story }\end{array}$ & Drift X & $\begin{array}{c}\mathrm{X}- \\
\text { Direction } \\
\Delta \mathrm{s}= \\
\text { (Dx).Cd/Ie }\end{array}$ & $\begin{array}{c}\Delta \mathrm{a}= \\
0,015 \\
\mathrm{H} / \rho\end{array}$ & $\begin{array}{c}\Delta \mathrm{s} \leq \\
\Delta \mathrm{a}\end{array}$ \\
\hline \multirow{2}{*}{$\begin{array}{c}X- \\
\text { Dire } \\
\text { ction }\end{array}$} & 2 & 2,0659 & 4 & 0,7531 & 2,7614 & 4,6154 & $\mathrm{OK}$ \\
\hline & 1 & 1,3128 & 4 & 1,3128 & 4,8136 & 4,6154 & $\begin{array}{c}\text { NOT } \\
\text { OK }\end{array}$ \\
\hline Code & $\begin{array}{l}\text { St } \\
\text { or } \\
y\end{array}$ & UX & $\begin{array}{l}\text { High } \\
\text { Story }\end{array}$ & Drift X & $\begin{array}{c}\mathrm{Y}- \\
\text { Direction } \\
\Delta \mathrm{s}= \\
(\mathrm{Dx}) . \mathrm{Cd} / \mathrm{Ie}\end{array}$ & $\begin{array}{c}\Delta \mathrm{a}= \\
0,015 \\
\mathrm{H} / \rho\end{array}$ & $\begin{array}{c}\Delta s \leq \\
\Delta \mathrm{a}\end{array}$ \\
\hline \multirow{2}{*}{$\begin{array}{c}\text { Y - } \\
\text { Dire } \\
\text { ction }\end{array}$} & 2 & 0,4114 & 4 & 0,1770 & 0,6490 & 4,6154 & $\mathrm{OK}$ \\
\hline & 1 & 0,2344 & 4 & 0,2344 & 0,8595 & 4,6154 & $\mathrm{OK}$ \\
\hline
\end{tabular}

\section{STRUCTURE STRENGTHENING WITH CONCRETE JACKETING}

Concrete jacketing is one of retrofitting structures used to the columns of the building. The demand for using concrete jackets to strengthen or repair reinforced concrete columns has been increasing in the past few decades [4]. Reinforced concrete jacketing is a common method for retrofitting existing columns with poor structural performance [5]. 
Jacketing implemented by enlarging the column section and increase the amount of reinforcement [6]. Retrofitting column with an effective jacketing can increase flexural, shear and axial strength column. Based on the results of research conducted by Fauzan et al [7,8], an increase in the capacity of a column in the round-jacketing on the building significant both flexural and shear capacity of the column by around $60 \%$.

\subsection{Detail of Column Cross Section}

Concrete jacketing is done by enlarging the cross-sectional dimensions and increase the amount of reinforcement column as can be seen in Figure 3. Jacketing the column is done by installing reinforcement enveloped the existing column [9]. In this study, the dimensions of rectangular columns were enlarged from $40 \times 40 \mathrm{~cm}^{2}$ to $55 \times 55 \mathrm{~cm}^{2}$ and for circular columns from $\phi 45 \mathrm{~cm}$ to $\phi 60 \mathrm{~cm}$. While, the steel reiforcement was added, $12 \mathrm{D} 19$ for rectangular columns and $16 \mathrm{~d} 19$ for circular columns. Shear reinforcement (strirrup) \$10-100 was installed to the added reinforcement. The concrete with compressive strenght of K-250 (fc'=22,5 Mpa) was used for this jacketed column.
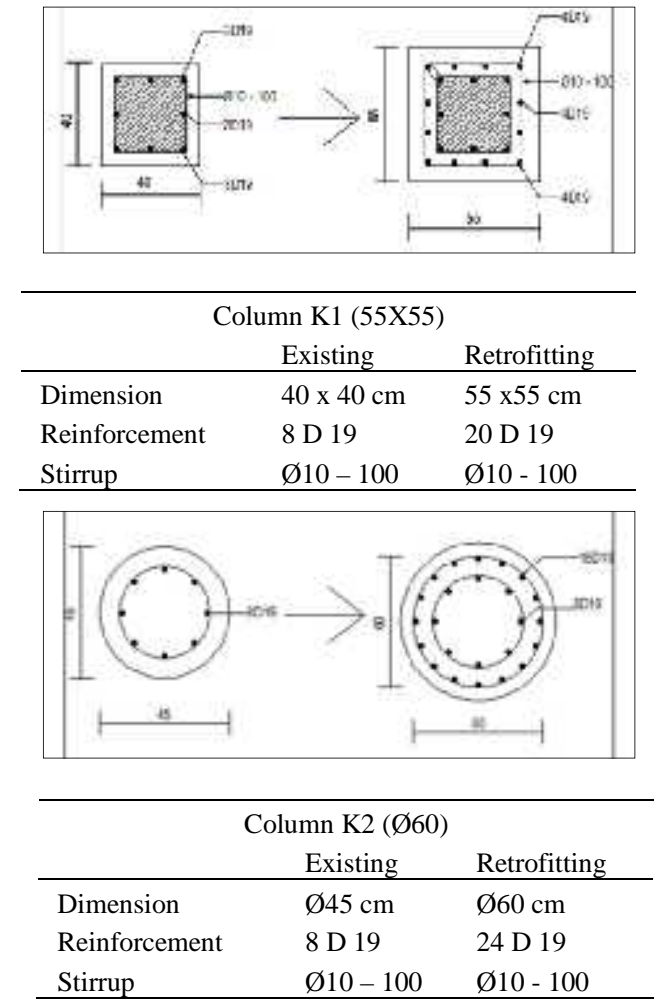

Fig 3. Dimensions and Cross Section of Existing and Retrofitting Column

\subsection{Analysis after jacketing}

Figure 4 shows P-M interaction diagram of column after strenghtening (retrofitting). As seen in the figure, the axial forces and bending moments are not exceed the interaction diagram, that means the capacity of column is strong enough to resist the working loads.
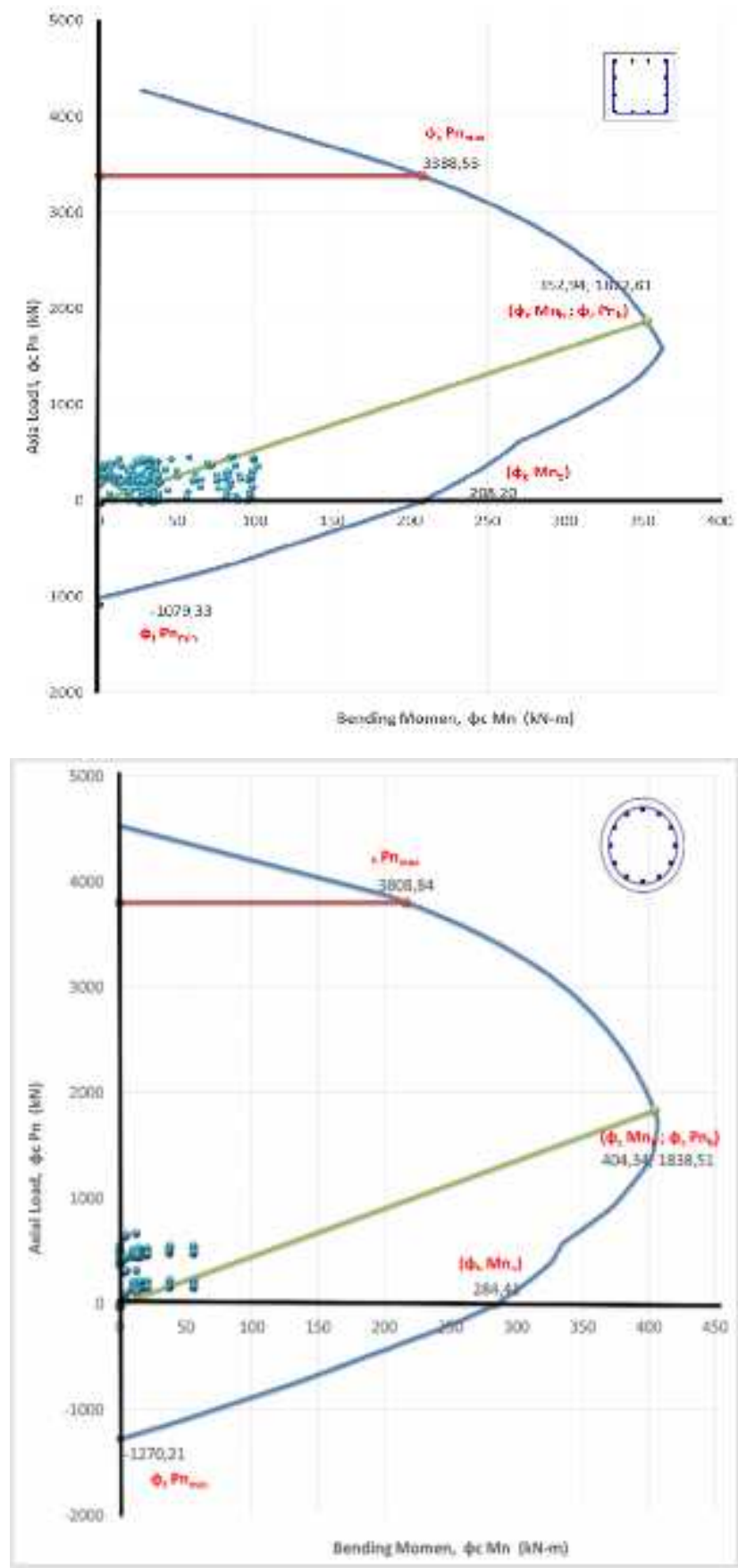

Fig 4. Interaction Diagram of Column After Retrofitting by Concrete Jacketing

Table 3.1 shows the comparation of column capacity on the first floor between existing and jacketted columns. As seen in the table, there is an significant increase on the column capacity after jacketing. The increased of moment capacity reached $70 \%$ compared to the existing condition, while for axial and shear forces reached $51 \%$ and $38 \%$, respectively.

The inter story drift of the building after retrofitting can be seen in table 3.2. From the table, it can be seen that the structure of the building after retrofitting has met the applicable requirements in seismic code SNI 17262012. 
Table 3.1 The Capacity of Column

\begin{tabular}{clccc}
\hline Code & \multicolumn{1}{c}{$\begin{array}{c}\text { Column } \\
\text { Capacities }\end{array}$} & $\begin{array}{c}\text { Existing } \\
\text { Condition }\end{array}$ & $\begin{array}{c}\text { Jacketing } \\
\text { Condition }\end{array}$ & $\begin{array}{c}\text { Increase of } \\
\text { Rasio (\%) }\end{array}$ \\
\cline { 2 - 3 } Column & Momet $(\mathrm{kNm})$ & 123,01 & 400,21 & 69,26 \\
K1 & Axial $(\mathrm{kN})$ & 1743,5 & 3584,75 & 51,36 \\
& Shear $(\mathrm{kN})$ & 223,27 & 361,26 & 38,20 \\
\hline \multirow{2}{*}{ Column } & Momet $(\mathrm{kNm})$ & 159,43 & 542,51 & 70,61 \\
K2 & Axial $(\mathrm{kN})$ & 2086,34 & 4257,84 & 51,00 \\
& Shear $(\mathrm{kN})$ & 254,63 & 386,24 & 34,07 \\
\hline
\end{tabular}

Table 3.2. Inter Story Drift of Bilding after Jacketting

\begin{tabular}{|c|c|c|c|c|c|c|c|}
\hline Code & Story & $\begin{array}{c}\mathrm{UX} \\
(\mathrm{cm})\end{array}$ & $\begin{array}{c}\text { High } \\
\text { Story } \\
(\mathrm{m})\end{array}$ & $\begin{array}{c}\text { Drift X } \\
(\mathrm{cm})\end{array}$ & $\begin{array}{c}\mathrm{X}- \\
\text { Direction } \\
\Delta \mathrm{s}= \\
(\mathrm{Dx}) \cdot \mathrm{Cd} / \mathrm{Ie}\end{array}$ & $\begin{array}{c}\Delta \mathrm{a}= \\
0,015 \\
\mathrm{H} / \rho\end{array}$ & $\begin{array}{c}\Delta \mathrm{s} \\
\leq \\
\Delta \mathrm{a}\end{array}$ \\
\hline \multirow{2}{*}{$\begin{array}{c}\mathrm{X}- \\
\text { Dire } \\
\text { ction }\end{array}$} & 2 & 1,5597 & 4 & 0,7595 & 0,7595 & 4,6154 & $\mathrm{OK}$ \\
\hline & 1 & 0,8002 & 4 & 0,8002 & 0,8002 & 4,6154 & $\mathrm{OK}$ \\
\hline Code & Story & $\begin{array}{l}\mathrm{UX} \\
(\mathrm{cm})\end{array}$ & $\begin{array}{c}\text { High } \\
\text { Story } \\
(\mathrm{m})\end{array}$ & $\begin{array}{c}\text { Drift X } \\
(\mathrm{cm})\end{array}$ & $\begin{array}{c}\mathrm{Y}- \\
\text { Direction } \\
\Delta \mathrm{s}= \\
(\mathrm{Dx}) . \mathrm{Cd} / \mathrm{Ie}\end{array}$ & $\begin{array}{c}\Delta \mathrm{a}= \\
0,015 \\
\mathrm{H} / \rho\end{array}$ & $\begin{array}{c}\Delta s \\
\leq \\
\Delta a\end{array}$ \\
\hline \multirow{2}{*}{$\begin{array}{l}\mathrm{Y}- \\
\text { Dire } \\
\text { ction }\end{array}$} & 2 & 0,4000 & 4 & 0,1798 & 0,1798 & 4,6154 & $\mathrm{OK}$ \\
\hline & 1 & 0,2202 & 4 & 0,2202 & 0,2202 & 4,6154 & $\mathrm{OK}$ \\
\hline
\end{tabular}

\subsection{Retroftting Implementation Method}

The first step of the retrofitting on the mosque was by eliminating the concrete cover of the existing column. Then, a reinforcement was added to the column. The concrete was cast after the formwork were installed. Concrete bond of SIKACIM was used to connect between the old and new concrete.
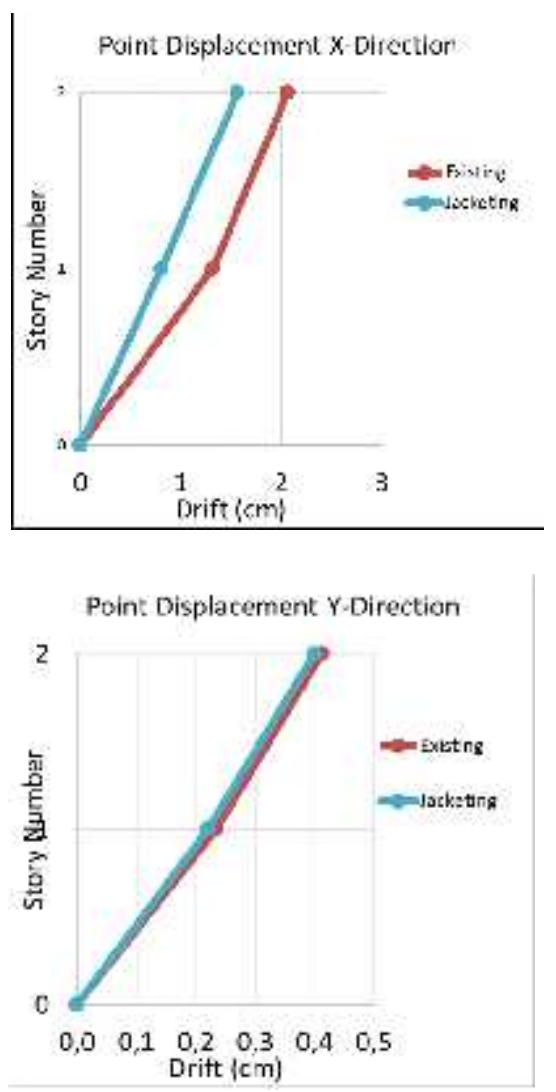

Fig. 5. Point Displacement

Implementation of the jacketing carried out on Nurul Ilmi Mosque building can be seen in Figure 6 .

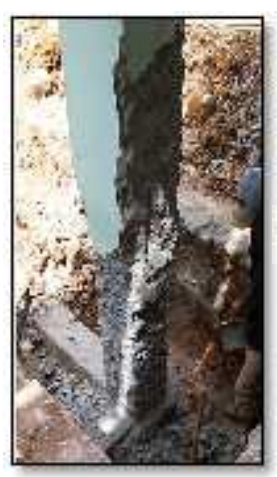

a.

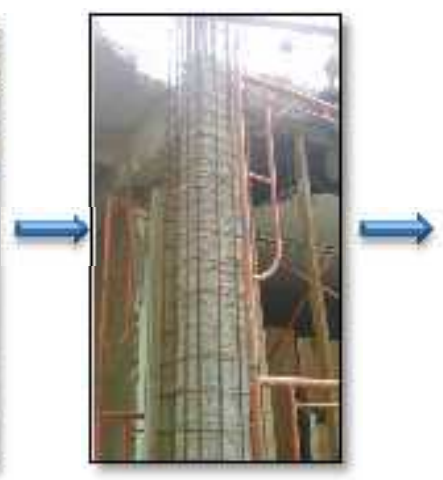

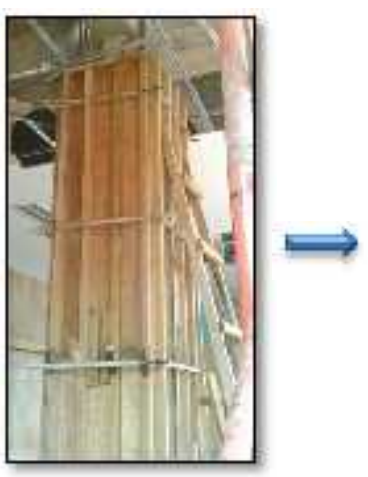

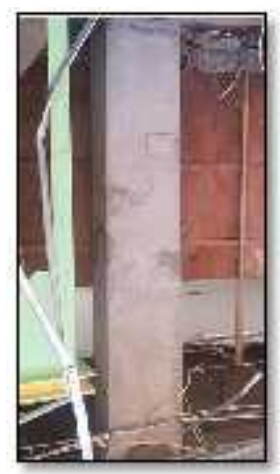

d.

a. Eliminate concrete column shelled approx $5 \mathrm{~cm}$ b. Installed the added reinforcement b. Installed formwork on enlarging of column dimensions and casting cocrete d. Column after jacketing

Fig. 6. Jacketing Method of Column 


\section{CONCLUSION}

1) The right side of Nurul Ilmi mosque is unable to resist the working loads based on SNI 03-1726-2012 and should be retrofitted before connecting it to the left side one.

2) Concrete Jacketting was recommended to Strengthening the mosque structure

3) Retrofitting with concrete jacketing increase the capacity of the column with a percentage increase for Moment, axial and shear are $69-70 \%, 51 \%$ and 30$40 \%$, respectively.

4) Retrofitting of the building using jacketing reduces displacements of the building structure.

5) The retrofitted mosque building meet requirement of the new seismic code, SNI 03-1726-2012 and has adequate capacity to resist the working loads.

\section{REFERENCES}

[1]. State Standardization Agency. 2002 Planning Procedures for Building Earthquake Resistance. ISO 1726: 2002. Jakarta

[2]. State Standardization Agency. 2012. Earthquake Resilience Planning Procedures for Building Structures and NonBuilding. ISO 1726: 2012. Jakarta.

[3]. Computers and Structures, Inc. 2005. Manual ETABS (Integrated Building Design Software). California, USA.

[4]. Elbakry, Hazem M.F. and Tarabia, Ahmed M. 2016. Factors affecting bond strength of RC column jackets. Alexandria Engineering Journal, Volume 55, Issue 1, March 2016, Pages 57-67

[5]. Minafò, Giovanni, et al. 2016.Strength and ductility of RC jacketed columns: A simplified analytical method. Engineering Structures, Volume 122,1 September 2016, Pages 184-195

[6]. Central Public Works Department and the Indian Building Congress. 2007. Handbook on Seismic Retrofit of Buildings. Association of Indian Institute of Technology.

[7]. Fauzan, et al. 2011. "Structural Failure Analysis and Retrofitting Mesjid Raya Andalas Padang Earthquake Post 30 Sept 2009". Journal of Civil Engineering. Volume 71 February 2011, ISSN 1558-2133.

[8]. Fauzan, et al. 2015. "Identification of Structural Damage and Strengthening Methods Office of the Governor of West Sumatra". Proceeding Senats 1 Udayana University. Bali.

[9]. Boen, Teddy. 2009. "How to Fix Simple Buildings Damaged in Earthquake". Jakarta. 